\title{
The Microbial Degradation of Cyclohexane Carboxylic Acid
}

\author{
By D. I. SMITH AND A. G. CALLELY \\ Department of Microbiology, University College, Cardiff, CF2 ITA
}

(Received 27 May 1975; revised Io July 1975)

\section{INTRODUCTION}

The microbial metabolism of both substituted and unsubstituted saturated cyclic compounds has received much less attention than the degradation of benzene ring compounds. Though the ability of bacteria to degrade alicyclic hydrocarbons has been reported on a number of occasions (see, for example, Imelik, I948; Ooyama \& Foster, I965; Fredericks, 1966; Jones \& Edington, I968; Beam \& Perry, 1973; Tonge \& Higgins, 1974), metabolic studies have centred upon the utilization of simple substituted derivatives such as cyclohexanol and cyclohexane carboxylic acid. Until recently, the only well-documented pathway for the aerobic dissimilation of such substances was that for the degradation of cyclohexanol by Nocardia globerula CLI (Norris \& Trudgill, 197I). Here cyclohexanol is converted to cyclohexanone from which $\epsilon$-caprolactone is produced. This is hydrolysed, the reaction being catalysed by $\epsilon$-caprolactone hydrolase, to give 6-hydroxycaproic acid; the latter is further oxidized to adipic acid, and ultimately to acetyl-CoA and succinyl-CoA.

This pathway thus involves hydrolytic cleavage of the still-saturated ring after initial oxidative steps. Blakley (1974) has since reported a different route by which an Arthrobacter sp. catabolized cyclohexane monocarboxylic acid (CHCA). Here, there is aromatization of the saturated growth substrate to form, ultimately, $p$-hydroxybenzoic acid before ring cleavage occurs. This possibility has also been suggested, by Tokuyama \& Kaneda (1973), who, on the basis of manometric data, considered that the metabolism of CHCA by Corynebacterium cyclohexanicum was closely related to that of benzoic acid; later Kaneda (1974) reported that extracts of this organism grown with CHCA catalysed the conversion of 4-ketocyclohexanecarboxylic acid to $p$-hydroxybenzoic acid. We have shown that our organism employs the same strategy when degrading CHCA, except that the subsequent metabolism of $p$-hydroxybenzoic acid follows a different route.

\section{METHODS}

The organism was isolated from marsh-mud near Penarth, South Glamorgan, by elective culture in medium with CHCA as the sole carbon and energy source. On morphological grounds it is considered to be an Arthrobacter sp.; young cultures consist of rods of irregular form and variable length which are Gram-negative, whereas aged cultures consist largely of Gram-positive coccoid forms. It was grown at $30^{\circ} \mathrm{C}$ in media containing (g/l distilled water): $\mathrm{KH}_{2} \mathrm{PO}_{4}, 2 ;\left(\mathrm{NH}_{4}\right)_{2} \mathrm{SO}_{4}, \mathrm{I} ; \mathrm{MgSO}_{4} .7 \mathrm{H}_{2} \mathrm{O}, 0.04$; with either CHCA, $p$-hydroxybenzoate or succinate $(5 \mathrm{mM})$ as the sole source of carbon and energy. The $\mathrm{pH}$ was adjusted to $7 \cdot 2$ with $\mathrm{NaOH}$ before sterlization, by autoclaving at $\mathrm{I}_{2 \mathrm{I}}{ }^{\circ} \mathrm{C}$. for $\mathrm{I} 5 \mathrm{~min}$. The $\mathrm{MgSO}_{4}(10 \%, \mathrm{w} / \mathrm{v})$ was sterilized separately, the required volume being added aseptically to the sterile solution of the other ingredients after cooling. The cultures were either shaken in an orbital incubator or had sterile air continually bubbled through them during growth. Stock cultures were main- 
tained either on nutrient-agar slopes or slopes of CHCA-mineral salts medium set with agar $(2 \%, w / v)$.

Organisms were harvested from 21 medium, after $24 \mathrm{~h}$ growth, by centrifugation at $10000 \mathrm{~g}$ and $4{ }^{\circ} \mathrm{C}$ for $\mathrm{IO} \mathrm{min}$. The pellet was washed once in phosphate buffer $\left(2 \mathrm{~g} \mathrm{KH}_{2} \mathrm{PO}_{4} / \mathrm{l}\right.$, adjusted to $\mathrm{pH} 7 \cdot 2$ with $\mathrm{NaOH}$ ) and finally resuspended in $5 \mathrm{ml}$ of the same buffer. To prepare extracts, such suspensions, previously cooled in and surrounded by ice, were sonicated for $4 \times 15 \mathrm{~s}$ with an MSE ultrasonic disintegrator. Any remaining intact organisms and debris were removed by centrifugation at $15000 \mathrm{~g}$ and $4{ }^{\circ} \mathrm{C}$ for $10 \mathrm{~min}$.

\section{RESULTS AND DISCUSSION}

Extracts of organisms grown with CHCA were devoid of any $\epsilon$-caprolactone hydrolase activity when this enzyme was assayed as described by Norris \& Trudgill (1971). Suspensions of the intact organism grown with CHCA did not oxidize adipic or pimelic acids at significant rates, as measured with a Gilson differential respirometer. (Manometer flasks contained, in a final volume of $3 \mathrm{ml}, 200 \mu \mathrm{mol}$ phosphate buffer, about $6 \mathrm{mg}$ dry wt organisms and, when present, 2 or $4 \mu \mathrm{mol}$ of substrate previously neutralized; centre wells contained $\mathrm{KOH}$ and a small piece of fluted filter paper; atmosphere, air; temperature, $30^{\circ} \mathrm{C}$.) Such a suspension did, however, readily oxidize the growth substrate, $p$-hydroxybenzoate and protocatechuate. The oxidation of these three substrates was not significantly altered when $300 \mu \mathrm{g}$ chloramphenicol was added to the reaction mixture, but they were not oxidized by suspensions of the organism grown with succinate.

Extracts of the organism grown with CHCA became yellow when incubated with protocatechuate. This yellow compound had spectral and chemical properties identical to those described for $\alpha$-hydroxy- $\gamma$-carboxy-cis: cis-muconic semialdehyde (Dagley, Evans \& Ribbons, I960): this is the compound produced by organisms that carry out a meta-cleavage of protocatechuate, catalysed by protocatechuate-4,5-oxygenase (EC. I.I3.I.8). The specific activity of this enzyme, assayed as described by Hegeman (I967), was 695 to $800 \mathrm{nmol}$ product produced $/ \mathrm{min} / \mathrm{mg}$ protein. The enzyme was barely detectable in similarly prepared extracts of the organism grown with succinate, when the highest value recorded was $20 \mathrm{nmol}$ product produced $/ \mathrm{min} / \mathrm{mg}$ protein. High activity was detected in extracts of $p$-hydroxybenzoate-grown organisms, as would be expected from the known pathways by which this compound is metabolized by bacteria; the specific activity was 600 to $750 \mathrm{nmol}$ product produced $/ \mathrm{min} / \mathrm{mg}$ protein, which was comparable to the values found in extracts prepared from CHCA-grown organisms. Protocatechuate-3,4-oxygenase (EC. I . I3 I .3) activity was never detected using the method described by Fujisawa (I970).

These results are consistent with metabolism of CHCA by this organism following a route whereby the saturated six-carbon ring of the growth substrate is converted to a benzenoid one in the compound $p$-hydroxybenzoate. This is converted to protocatechuate, whose benzene nucleus is then opened by meta-cleavage. In this respect it differs from the pathway for metabolism of CHCA found in the Arthrobacter sp. studied by Blakley (1974) where ortho-cleavage of protocatechuate occurs catalysed by protocatechuate-3,4-oxygenase.

In their taxonomic study of the pseudomonads, Stanier, Palleroni \& Doudoroff (I966) showed that the mode of ring cleavage of protocatechuate is a taxonomically significant character, as all the strains of a given Pseudomonas that were able to perform this reaction used the same mode. This could also be the case with the various arthrobacters.

We acknowledge Flavia R. Evans, D. K. Necklen, A. H. Pickaver, P. Dukes and Delyth 
H. Davies, who studied this organism in their final-year Honours degree project in this department, and particularly the first named who was responsible for isolating it in 1966 . We also thank D. R. Kitto and P. McGarry for technical assistance.

\section{REFERENCES}

BeAm, H. W. \& Perry, J. J. (I973). Cometabolism as a factor in microbial degradation of cycloparaffinic hydrocarbons. Archiv für Mikrobiologie 91, 87-90.

BLAKLEY, E. R. (1974). The microbial degradation of cyclohexanecarboxylic acid: a pathway involving aromatization to form a $p$-hydroxybenzoic acid. Canadian Journal of Microbiology 20, I 297-1 306.

Dagley, S., Evans, W. C. \& RibBons, D. W. (1960). New pathways in the oxidative metabolism of aromatic compounds by microorganisms. Nature, London 188, 560-566.

FREDERICKS, K. M. (1966). Adaptation of bacteria from one type of hydrocarbon to another. Nature, London 209, 1047.

FujisawA, H. (1970). Protocatechuate-3:4-dioxygenase (Pseudomonas). Methods in Enzymology 17 A, 526-529.

HegemaN, G. D. (1967). The metabolism of $p$-hydroxybenzoate by Rhodopseudomonas palustris and its regulation. Archiv für Mikrobiologie 59, I43-I48.

IMELIK, B. (1948). Oxidation of cyclohexane by Pseudomonas aeruginosa. Comptes rendus hebdomadaire des séances de l'Académie des sciences 226, 2082-2083.

Jones, J. G. \& EDINGTON, M. A. (1968). An ecological survey of hydrocarbon-oxidizing micro-organisms. Journal of General Microbiology 52, 38I-390.

KANEDA, T. (1974). Enzymatic aromatization of 4-ketocyclohexanecarboxylic acid to $p$-hydroxybenzoic acid. Biochemical and Biophysical Research Communications 58, 140-44.

Norris, D. B. \& Trudgill, P. W. (I97I). The metabolism of cyclohexanol by Nocardia globerula cli. Biochemical Journal 121, 363-370.

Ooyama, J. \& Foster, J. W. (I965). Bacterial oxidation of cycloparaffinic hydrocarbons. Antonie van Leeuwenhoek 31, 45-65.

Stanier, R. Y., Palleroni, N. J. \& Doudoroff, M. (1966). The aerobic pseudomonads: a taxonomic study. Journal of General Microbiology 43, I 59-27I.

Tokuyama, T. \& Kaneda, T. (1973). Corynebacterium cyclohexanicum n.sp.: a cyclohexanecarboxylic acid utilizing bacterium. Canadian Journal of Microbiology I9, 937-942.

ToNGE, G. M. \& HigGiNs, I. J. (I974). Microbial metabolism of alicyclic hydrocarbons. Growth of Nocardia petroleophila (NCIB9348) on methylcyclohexane. Journal of General Microbiology 8I, 52 I-524. 